\title{
A Case with Methemoglobinemia due to Use of Dapsone*
}

\section{Dapsone Kullanımına Bağlı Gelişen Methemoglobinemi Olgusu}

Emine Aksoy, Özlem Yazıcıoğlu Moçin

\section{Abstract}

Methemoglobinemia is a lethal condition that is most commonly seen with use of drugs such as dapsone and Benzocain. Methemoglobinemia associated with dapsone use is a result of decreased oxidation in erythrocytes due to the inhibition of the B5 reductase enzyme. We present here a case who developed methemoglobinemia while taking dapsone $100 \mathrm{mg} /$ day for a month due to urticaria. The male patent developed such symptoms as malaise, subfebrile fever, sweating, peri-oral and peripheral cyanosis with exertion, and skin lesions for a week. Oxygen saturation with pulse oxymetry was $88 \%$, and the methemoglobin (MetHb) level in the arterial blood gases (ABG) was $10.7 \%$ at time of diagnosis. The patient was monitored, oxygen was initiated and dapsone was discontinued. The patient recovered during follow-up and the MetHb level became normal (2.8\%) in ABG on the 7th day, and the cyanosis disappeared. Patients presenting with cyanosis and with no known previous pulmonary or cardiac disease should be evaluated for Methemoglobinemia, and drug history of the patient should also be reviewed.

\section{Özet}

Methemoglobinemi, sıklıkla Dapsone ve Benzocain gibi ilaçların kullanımıyla ortaya çıkan hayatı tehdit eden bir durumdur. Dapson, B5 redüktaz enzimini inhibe ederek eritrositlerde oksidasyonu azaltarak methemoglobinemiye neden olur. Bu makale de ürtiker nedeniyle bir ay boyunca 100 mg / gün dapson kullanan methemoglobinemi olgusu sunuldu. Hasta bir haftadır devam eden eforla halsizlik, ateş, terleme, peri-oral, periferik siyanoz ve cilt lezyonları ile başvurdu. Pulse oksimetre ile ölçülen oksijen satürasyonu \%88 idi. Arteryel kan gazındaki (AKG) methemoglobin (MetHb) seviyesi tanı anında \%10,7 idi. Hastanın takibinde, oksijen desteği verildi ve Dapsone tedavisi kesildi. Hasta klinik takipte iyiydi ve 7 . günde AKG'da MetHb düzeyi normal sınılardaydı $(\% 2,8)$ ve siyanoz saptanmadı. Daha önce akciğer veya kalp hastalığı olmayan siyanoz ile başvuran bir hastada methemoglobinemi akılda tutulmalı ve ilaç öyküsü de sorgulanmalıdır.

Anahtar Sözcükler: Dapson, Methemoglobinemi, llaca bağlı komplikasyonlar.

Key words: Dapsone, Methemoglobinemia, Drugrelated complications.

University of Health Sciences Süreyyapaşa Chest Diseases and

Thoracic Surgery Education and Research Hospital, İstanbul, Turkey

Sağlık Bilimleri Üniversitesi Süreyyapaşa Göğüs Hastalıkları ve Göğüs Cerrahisi Eğitim ve Araşııma Hastanesi, İstanbul

Submitted (Başvuru tarihi): 23.1 1.2020 Accepted (Kabul tarihi): 17.03.2021

Correspondence (iletişim): Emine Aksoy, University of Health Sciences Süreyyapaşa Chest Diseases and Thoracic Surgery Education and Research Hospital, ìstanbul, Turkey

e-mail: dremineaksoy95@gmail.com

*This case named "A case with methemoglobinemia due to use of Dapsone" was presented as a Case Counsil presentation at the 41 st National Congress of TÜSAD on October 26-29, 2019 
Methemoglobinemia is a lethal condition that develops with use of chemicals, medicine and congenital enzyme deficiency in children (1). Dapsone is an antibiotic in the sulphone group with anti-inflammatory and anti-bacterial effects. Methemoglobinemia associated with dapsone occurs with decreased oxidation in the erthrocytes and an inhibited B5 reductase enzyme (2). Treatment involves the use of Methylene blue, ascorbic acid, hemodialysis and supportive treatment (3). We present here a case with methemoglobinemia associated with the use of dapsone $100 \mathrm{mg} /$ day for a month for the treatment of urticaria.

\section{CASE}

We report here on the case of a 60-year-old male 10 year ex-smoker with a 10 pack-year history with a history of urticaria and gastritis. The patient's mother and father had died of pancreas and colon cancer, respectively. The patient had been using dapsone $100 \mathrm{mg} /$ day, desloratadine $5 \mathrm{mg} /$ day and cetirizine dihydrochloride $10 \mathrm{mg} /$ day for one month, and. presented with malaise, sub-febrile fever, sweating, peri-oral and peripheral cyanosis with exertion, and skin lesions for a week. His vital signs were: blood pressure, $125 / 75 \mathrm{mmHg}$; pulse rate, $105 / \mathrm{min}$; respiratory rate, $18 / \mathrm{min}$; temperature, $37.5^{\circ} \mathrm{C} ; \mathrm{O}_{2}$ saturation $\left(\mathrm{SaO}_{2}\right), 88 \%$. Peri-oral cyanosis and urticarial skin lesions that were puffy, dark red in color and with $1 \times 2 \mathrm{~cm}$ dimensions with prominent borders were detected (Figure 1 and 2). Other system examinations were normal. The laboratory results were: Leucocytes, 9.7 10\% $/ \mathrm{L}$; hemoglobin $(\mathrm{Hb}), 11.5 \mathrm{~g} / \mathrm{dl}$; platelets, 337 10\%/L; eosinophil, 0.9\%; C-reactive protein, $86.5 \mathrm{mg} / \mathrm{dl}$; glucose, $110 \mathrm{mg} / \mathrm{dl}$; urea, $26 \mathrm{mg} / \mathrm{dl}$; creatinine, $0.72 \mathrm{mg} / \mathrm{dl}$; aspartate transfarase, $61 \mathrm{U} / \mathrm{L}$; alanine transfarase, $80 \mathrm{U} / \mathrm{L}$; arterial blood gas (ABG) analysis, $\mathrm{pH}, 7.46 ; \mathrm{pCO}_{2}, 34.2 ; \mathrm{pO}_{2}, 76.9 \mathrm{mmHg}$; $\mathrm{HCO}_{3}, 25.6$; BaseEc, $1.5 \mathrm{mmol} / \mathrm{L}$; methemoglobin (MetHb), 10.7\%; carboxyhemoglobin (COHb), $0 \%$; $\mathrm{SaO}_{2}$, 94\%. Pulmonary function tests, electrocardiogram and echocardiography were normal, although grade I diastolic dysfunction was detected. An allergy and Immunology consultation was made. No pathology was identified from a chest X-ray and thorax computed tomography (CT), while bilateral renal cortical cysts were detected during an abdomen USG (Figure 3, 4a-4f). The patient was monitored, $\mathrm{O}_{2}$ support was given, and Dapsone was withdrawn. The patient was well in clinical follow-up, with a MetHb level within normal limits $(2.8 \%)$ in an $A B G$ taken on 7th day, and no cyanosis was detected $\left(\mathrm{SaO}_{2}, 96 \%\right)$.

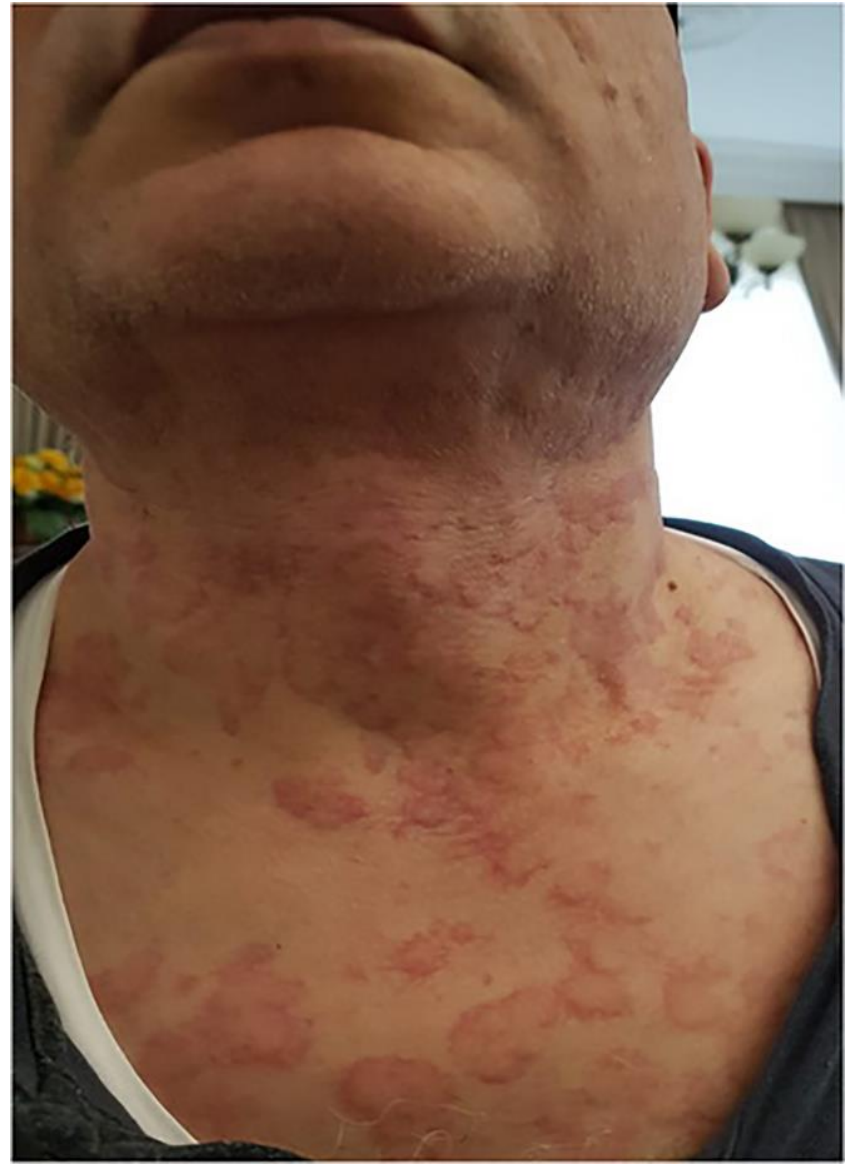

Figure 1: Skin lesion at neck region

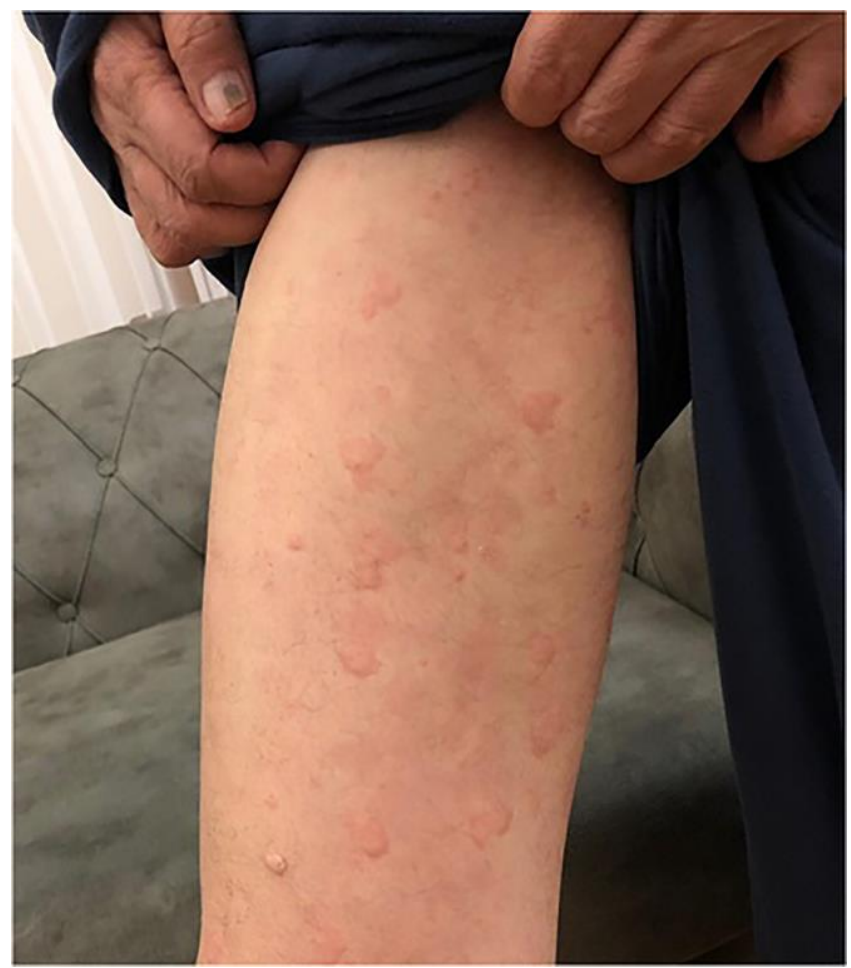

Figure 2: Skin lesion at right leg 


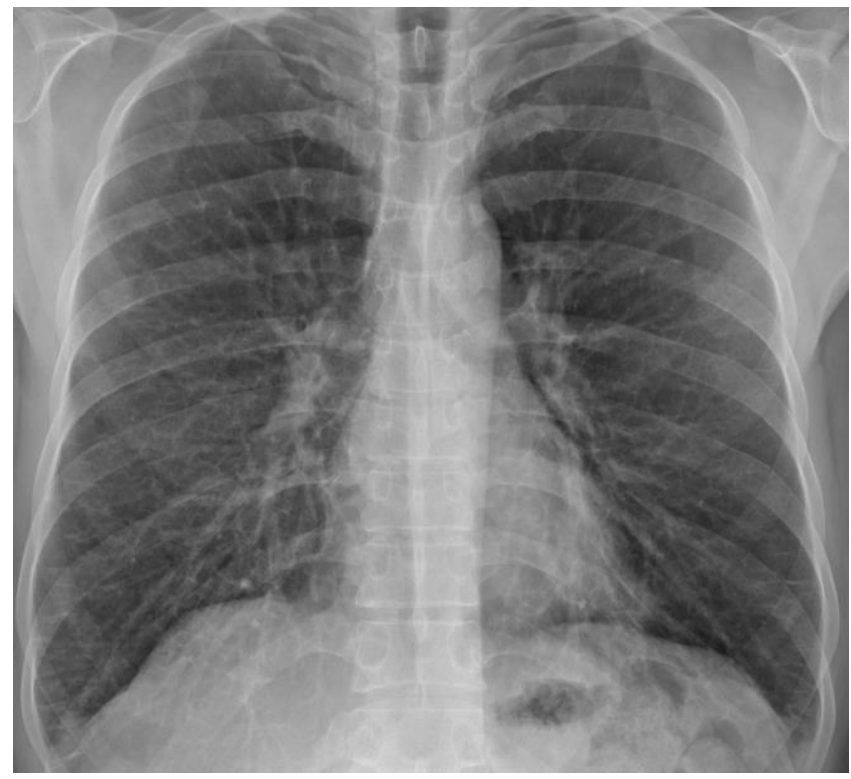

Figure 3: Chest $X$-ray of the patient

\section{DISCUSSION}

MetHb is formed during the oxidation of iron from its ferrous form $(\mathrm{Fe} 2+)$ to ferric form $(\mathrm{Fe} 3+)$ in hemoglobin molecules. MetHb levels are below $1 \%$ of total hemoglobin under normal conditions. In Methemoglobinemia, the oxygen carrying capacity of $\mathrm{Hb}$ is destroyed and tissue oxygenation decreases, which can be due to congenital or acquired causes (1). The congenital causes of methemoglobinemia are cytochrome b5 reductase deficiency, presence of hemoglobin $M$, glucose-6-phosphate deficiency (G6PD), and nicotinamide adenine dinucleotide phosphate (NADPH)-MetHb reductase deficiency (1). Toxins and medications are the most common sources of acquired methemoglobinemi, and dapsone and benzocaine are the most commonly encountered medications. Aniline dyes, herbicides, foods containing nitrate, pesticides, petrol octane boosters and mothballs are frequent toxic agents (1).

Dapsone is a sulphon group antibiotic with antiinflammatory and anti-microbial effects that inhibits folate synthesis (2). It was first used in 1940 for the treatment of Lepra, and has also been used for the treatment of different dermatologic diseases characterized by neutrophil and eosinophil accumulation $(2,4)$. Dapsone is metabolized in the liver by acetylation and $\mathrm{N}$-hydroxylation. Mono-acetyldapsone, a non-toxic metabolite, is produced by acetylation, however the toxic metabolite dap- sone hydroxylamine is produced by $\mathrm{N}$-hyrdoxylation within the P-450 enzyme system. Hydroxylamine destroys the oxidation of $\mathrm{Hb}$ in erythrocytes $(4,5)$.

The initial dose of dapsone is usually $50 \mathrm{mg} /$ day, and $100-200 \mathrm{mg} /$ day is sufficient in most cases. As sideeffects are dose-dependent, the suggested daily dose is $100 \mathrm{mg}$. Prior to the initiation of dapsone, a complete blood count $(\mathrm{CBC})$, blood biochemistry and urine analysis should be carried out (4). Dapsone should be used with caution in G6PD enzyme deficiency, MetHb reductase deficiency, in patients with severe liver, heart and lung diseases, and in patients using medications that induce methemoglobinemia. The maximum MetHb level is reached after six hours of ingestion with just a single dose, and so the MetHb level should be checked 4-6 hours after ingestion. The most common side-effects of dapsone are methemoglobinemia and hemolysis. In our case, methemoglobinemia was detected following the ingestion of dapsone $100 \mathrm{mg} /$ day for a month. Peripheral neuropathy, agranulocytosis due to bone marrow suppression, gastrointestinal issues (anorexia, nausea, vomiting, abdominal pain) and hypersensitivity syndrome constitute the other side-effects $(4,5)$.

All symptoms and signs are related to the level of MetHb. Central and peripheral cyanosis is seen at a MetHb level of 15\%; headache, malaise, tiredness, tachycardia and dizziness are detected at a MetHb level of 30-45\%; and cardiac arrhythmia, dyspnea, seizure and coma are seen at a $60 \%$ level. Death occurs when the MetHb level is more than $70 \%$ (6). The MetHb level in our case was $10.7 \%$ at the time of diagnosis.

Due to the non-specific symptoms in clinical practice, the diagnosis of methemoglobinemia may be difficult. Patients with methemoglobinemia frequently present with cyanosis, and methemoglobinemia should be kept in mind in adult patients with cyanosis that cannot be explained by respiratory or cardiac causes, and that cannot be resolved with $\mathrm{O}_{2}$ therapy. In patients with methemoglobinemia, $\mathrm{SaO}_{2}$ is measured at around $80-85 \%$, independent of the real partial pressure of $\mathrm{O}_{2}\left(\mathrm{PaO}_{2}\right)$ and $\mathrm{MetHb}$ level. A diagnosis of methemoglobinemia can be confirmed from the direct measurement of the MetHb level in the blood. 

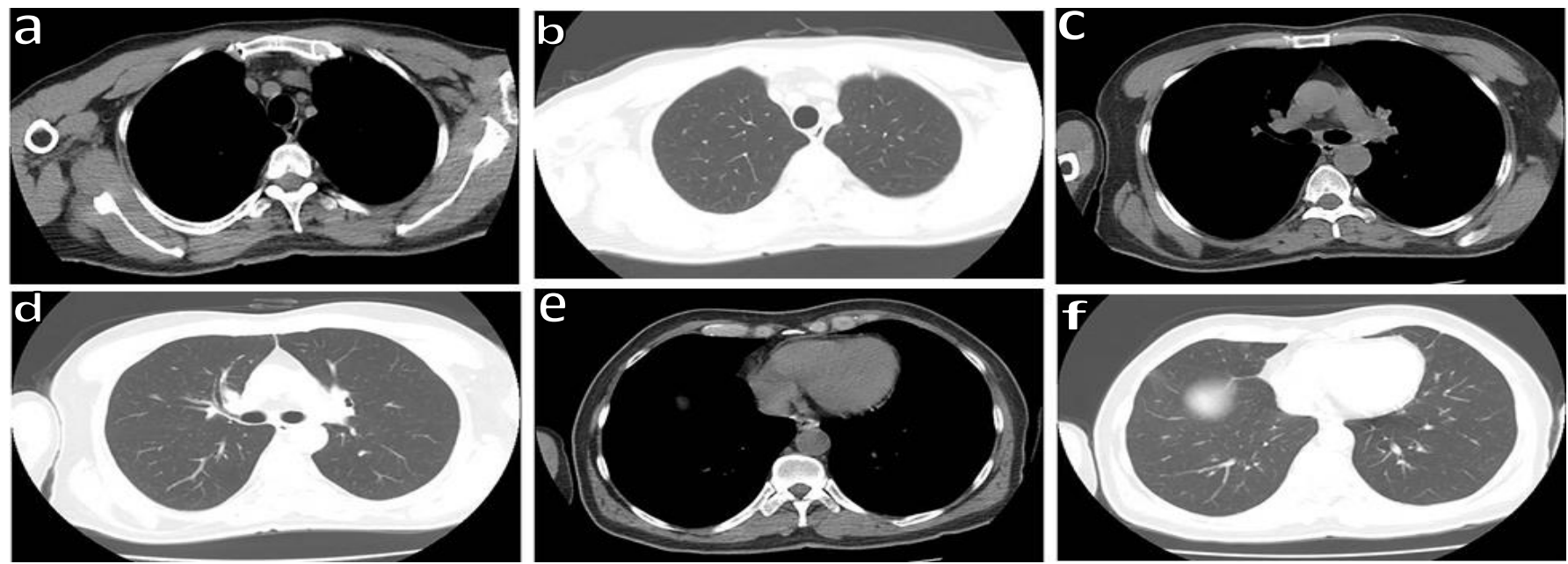

Figure $4 a, b, c, d$, e and $f$ : Chest CT of the patient

The basis of treatment of acquired methemoglobinemia is the identification and withdrawal of the offending agent, and the cessation of medication alone is sufficient for treatment of medication induced methemoglobinemia when the level of MetHb is below 20\%. Monitorization and supportive treatment are very important for higher levels of MetHb. High-flow $\mathrm{O}_{2}$ therapy is initiated to improve tissue oxygenation, and we used also supportive $\mathrm{O}_{2}$ therapy with the cessation of medication in our case, leading to the cessation of cyanosis at follow up. However, if the level of MetHb is greater than 30\%, the intravenous use of $1-2 \mathrm{mg} / \mathrm{kg}$ methylene blue is proposed. If the cyanosis does not resolve within an hour of initiation of methylene blue, the same dose can be repeated. Hyperbaric $\mathrm{O}_{2}$ treatment is advised if methylene blue is contraindicated due to its toxic effects. As it is non-effective and increases the risk of hemolysis and paradoxal methemoglobinemia, Methylene blue is contraindicated for patients with G6PD deficiency (1), and ascorbic acid can be used in such cases.

\section{CONCLUSION}

Methemoglobinemia is attributable to medications in the majority of cases, and so it is crucial to inquire about medication history. In this case presentation, our emphasis is on methemoglobinemia in the differential diagnosis of a patient presenting with cyanosis with no previous pulmonary or cardiac diseases, and the need to ascertain the patient's medication history.

\section{CONFLICTS OF INTEREST}

None declared.

\section{AUTHOR CONTRIBUTIONS}

Concept - E.A., Ö.Y.M.; Planning and Design - E.A., Ö.Y.M.; Supervision - E.A., Ö.Y.M.; Funding - E.A., Ö.Y.M.; Materials - E.A., Ö.Y.M.; Data Collection and/or Processing - E.A.; Analysis and/or Interpretation E.A., Ö.Y.M.; Literature Review - H.F.A., G.K.K.; Writing - E.A., Ö.Y.M.; Critical Review - E.A., Ö.Y.M.

\section{YAZAR KATKILARI}

Fikir - E.A., Ö.Y.M.; Tasarım ve Dizayn - E.A., Ö.Y.M.; Denetleme - E.A., Ö.Y.M.; Kaynaklar - E.A., Ö.Y.M.; Malzemeler - E.A., Ö.Y.M.; Veri Toplama ve/veya İşleme - E.A.; Analiz ve/veya Yorum - E.A., Ö.Y.M.; Literatür Taraması - H.F.A., G.K.K.; Yazıyı Yazan - E.A., Ö.Y.M.; Eleştirel İnceleme - E.A., Ö.Y.M.

\section{REFERENCES}

1. Skold A, Cosco DL, Klein R. Methemoglobinemia: pathogenesis, diagnosis, and management. South Med J $2011 ; 104: 757-61$. [CrossRef]

2. Barclay JA, Ziemba SE, Ibrahim RB. Dapsone-induced methemoglobinemia: a primer for clinicians. Ann Pharmacother 201 1; 45:1 103-15. [CrossRef]

3. Mahmood N, Khan MU, Haq IUL, Jelani FA, Tariq A. A case of Dapsone induced methemoglobinemia. J Pharm Policy Pract 2019; 12:22. [CrossRef]

4. Koca R. Dapson. Turkiye Klinikleri J Dermatol-Special Topics 2014; 7: 43-8.

5. Wozel G, Blasum C. Dapsone in dermatology and beyond. Arch Dermatol Res 2014; 306:103-24. [CrossRef]

6. Burke P, Jahangir K, Mr K, Kolber MR. Dapsone-induced methemoglobinemia: case of the blue lady. Can Fam Physician 2013; 59: 958-61. 